\title{
STENOSIS DETECTION IN INTERNAL CAROTID AND VERTEBRAL ARTERIES WITH THE USE OF DIAMETERS ESTIMATED FROM MRI DATA
}

\author{
I. Nesteruk $^{1^{*}}$, S. Pereverzyev Jr. ${ }^{2 \#}$, L. Mayer ${ }^{2}$, R. Steiger ${ }^{2 \#}$, L. Kusstatscher ${ }^{2}$, K. Fritscher ${ }^{3}$, M. Knoflach ${ }^{2}$, E.R. Gizewski ${ }^{2 \#}$ \\ ${ }^{1}$ Igor Sikorsky Kyiv Polytechnic Institute, Kyiv, Ukraine \\ ${ }^{2}$ Medical University of Innsbruck, Innsbruck, Austria \\ ${ }^{3}$ University for Health Sciences, Medical Informatics and Technology, Hall in Tirol, Austria \\ *Corresponding author: inesteruk@yahoo.com \\ "Neuroimaging Research Core Facility
}

Received 1 June 2020; Accepted 29 June 2020

\begin{abstract}
Background. Magnetic resonance imaging (MRI) offers the opportunity to quantify the vessel diameters in vivo. This technique can have a breakthrough impact on the evaluation, risk stratification and therapeutical planning in hemodynamic-related pathologies, e.g., arterial stenosis. However, its applicability in clinics is limited due to the complex post-processing required to extract the information and the difficulty to synthesize the obtained data into clinical useful parameters.

Objective. In this work, we use the vessel diameter distribution along its central line obtained with the use of MRI technology in order to detect the existence of stenosis in internal carotid arteries (ICA) and vertebral arteries (VA) with the minimal amount of False Negative predictions and to estimate the efficiency of therapy. Methods. Special normalized and smoothed characteristics will be used to develop the stenosis detection criteria which can be used for every artery separately and for both vessels simultaneously. Linear and non-linear characteristics were used to increase the reliability of diagnostics. Study is based on the Receiver Operating Characteristics (ROC) and optimization methods. Real diameter data of 10 patients (80 data sets) were used. Results. To detect stenosis, three different criteria have been proposed, based on the optimal smoothing parameters of vessel diameter distributions and the corresponding threshold values for linear and nonlinear characteristics. The use of the developed criteria allows increasing the reliability of stenosis detection.

Conclusions. Different linear, non-linear, smoothed and non-smoothed parameters and ROC were applied to detect stenosis in internal carotid and vertebral arteries. It was shown that smoothed data are necessary for VA and the criterion applicable both for VA and ICA. For ICA it is possible to use initial (unsmoothed) data. Only one False Positive case was detected for every artery. Results of application of proposed criteria are presented, tested and discussed. For VA it is possible to use criteria 1 and 2 and smoothed normalized diameter data. For ICA criterion 2 can be recommended to detect long enough narrowing areas. To detect short zones of stenosis in ICA, the criterion 3 is useful, since it uses the non-smoothed diameter data.
\end{abstract}

Keywords: stenosis; internal carotid arteries; vertebral arteries; magnetic resonance imaging; computerized angiography; receiver operating characteristic; optimization.

\section{Introduction}

In this paper, we discuss the automatic detection of stenosis from the estimated diameters of cross-sectional areas of a blood vessel. Such a detection problem can appear at the quantification stage of Computerized Angiography that is based on digital image processing and important in conventional radiology. The survey [1] contains a profound overview of stenosis detection methods. The algorithms discussed there have been developed for the coronary artery stenosis detection, but in principle, they can also be used for diagnosing stenosis of other types of arteries, such as cervical arteries that are of our main interest here.

Among the methods overviewed in the above mentioned survey, the algorithm proposed in [2] outperforms the others and can be considered as state-of-the-art one. In this algorithm, the stenoses are subsequently detected and quantified by computing the relative change between the estimated and expected diameter profiles.

One important requirement formulated in [1] states that a fully automatic algorithm should be able to identify stenosis-free arteries with high specificity (above 0.6 ) to not overwhelm with a considerable amount of false positive detections. Note that although on the datasets considered in our study, the algorithm proposed in [2] performs even better than it has been reported in [1], for some types of arteries the specificity 0.636 exhibited by the algorithm is too close to the above indicated low limit of 0.6 .

Thus, it would be desirable to further improve the stenosis detection performance. The present study is aimed at addressing this need. 


\section{Materials and methods}

\section{Information collection}

In this research we use the data of patients suffering a spontaneous cervical artery dissection until 2017, who were treated at the Department of Neurology, Medical University of Innsbruck, within the ReSect-study [3]. We selected the data of 10 patients with stenotic cervical artery dissection at the study baseline (date A). All patients received 3T whole body magnetic resonance angiography (MRA) at the Neuroimaging Research Core Facility of the Medical University of Innsbruck, equipped with a 3T whole body system (Verio, Siemens, Erlangen, Germany) employing a 12-channel head coil and an additional neck-coil. The right and left internal carotid arteries (ICA) and vertebral arteries (VA) were segmented from the MRA images using ITK-SNAP program (www.itksnap.org) [4]. For the determination of the diameter and position data from the segmentations at baseline (date A) and follow-up (date B) we used VMTK program (www.vmtk.org). After segmentation only the cases with a clear diagnosis were used for testing stenosis detection algorithms. Consequently, the data of 38 ICA and 39 VA were analyzed.

It must be noted that problem of vessel segmentation with the use of MRI data is complicated and requires a lot of effort and appropriate skills [5-12]. In particular, a hydrodynamics-based algorithm was proposed in [11] for automatic segmentations of large vessels, calculations of their radius and other characteristics versus distance along the central line.

\section{Normalized and smoothed characteristics}

Different patients and even one patient before and after treatment may have substantially different sets for a characteristic $c_{j}$ (e.g., artery diameter $d_{j}$ ), its averaged values of $\bar{c}$ and root-mean-square deviations:

$$
\bar{c}=\frac{1}{n} \sum_{j=1}^{n} c_{j} ; \quad \sigma^{2}=\frac{1}{n-1} \sum_{j=1}^{n}\left(c_{j}-\bar{c}\right)^{2} .
$$

In particular, the average diameter of VA increased by $33 \%$ after the patient P1 treatment. In order to develop universal criteria (applicable for different patients), we will use the normalized characteristics according to the following formula:

$$
C_{i}=\frac{c_{i}-\bar{c}}{\bar{c}} .
$$

To diminish the noise, we will use also smoothed and smoothed normalized characteristics:

$$
t_{i}=\frac{1}{n_{i}} \sum_{j=i-w, j>0}^{j=i+w, j \leq n} c_{j} ; \quad T_{i}=\frac{1}{n_{i}} \sum_{j=i-w, j>0}^{j=i+w, j \leq n} C_{j} .
$$

Where $w$ is the width of smoothing (in particular, $w=0$ means using the initial distributions without any smoothing); $n_{i}$ is number of indexes between $j=i-w, j>0$ and $j=i+w, j<n+1$; and $n$ is the number of elements in a data set (can be different for different patients and arteries). We will try to use different values of the width of smoothing in order to find the optimal and universal stenosis detection criteria.

\section{Deviations from average values}

Similar to [13], we will treat a zone of possible stenosis as a narrowing between two adjacent points with average values of the characteristic. If the minimal value of a characteristic in this area $T_{\min }$ is smaller than certain threshold, the stenosis is flagged. Thus, for every characteristic the value of deviation $V=\left|T_{\min }\right|$ will be calculated with the use of developed Matlab code.

To compare the results, we will use also the deviations of non-normalized characteristics $v=\left|t_{\min }\right|$ and a special criterion $k$, calculated according to the formula:

$$
k=\frac{v-\sigma}{\sigma} \times 100 \% .
$$

In the cases, when there are no two adjacent points with average values of the characteristic, the value of deviation and criterion $k$ are supposed to be zero.

\section{Use of Receiver Operating Characteristic}

To compare the effectiveness of criteria we will use Receiver Operating Characteristic (ROC) methods. In particular, we will calculate the area under the ROC curve $(A U C)$, sensitivity $(S E)$, specificity $(S P)$, positive predictive value $P P V$ and $F_{1}$ score according to the known formulas [14]:

$$
\begin{gathered}
S E=\frac{T P}{T P+F N}, \quad S P=\frac{T N}{T N+F P}, \\
P P V=\frac{T P}{T P+F P}, \quad F_{1}=\frac{2}{1 / S E+1 / P P V} .
\end{gathered}
$$

Here $T N$ is the total number of true negative predictions; $T P$ is the total number of true positive 
predictions; $F N$ is the total number of false negative ones; $F P$ is the total number of false positive ones.

To calculate these characteristics, 39 data sets were used for VA (without P10-A-left, diagnosis "closed") and 38 data sets for ICA (without P2-Bright and P5-B-left, diagnosis "improved"). Thus, to develop the reliable criteria, we will use only cases with a clear stenosis diagnosis (yes or no). Later we will discuss mentioned above unclear cases and their influence on the results.

It is very important to have a criterion minimizing not only the number of errors $(F P+F N)$, but also the number of $F N$ diagnoses. With the use of such approach we will minimize the number of really ill persons, who are not identified. The developed Mathlab code minimizes $F P+F N$, searches the cases with $F N=0$, calculates the corresponding values of thresholds and indicates the number of the set with the false positive prediction.

\section{Results}

\section{Different criteria applied for $V A$ diameter dis- tribution}

The results of calculations with the use of VA diameter data sets are presented in Figs. 1-3. In these figures (and also in Figs. 8, 13, and 14), blue lines represent the AUC; black lines $-F_{1}$; red lines minimum and maximum values of the threshold; red stars - sum of false negative predictions $F N$, black circles $-F P$. All the characteristics are plotted versus the width of smoothing $w$. We have used normalized smoothed VA diameter (second formula (1), Fig. 1); non-normalized VA diameter (first formula (1), Fig. 2) and $k$-parameter (eq. (2), Fig. 3).

Figs. 1 and 2 demonstrate that for some values of $w$, it is possible to have only one error $F P+F N=1$ and no false negative predictions $(F N=0)$. The corresponding ranges are $15 \leq w \leq 46$ and $34 \leq w \leq 41$ for normalized and non-normalized diameter respectively. In both ranges the false positive prediction correspond to the same data set (P1-B-right). With the use of $k$-parameter the number of errors is greater than $1(F P+F N>1)$ for all $0 \leq w \leq 100$ (see Fig. 3).

Comparison of the Figs. 1-3 show that using the smoothed normalized diameter is preferable, since it ensures smaller number of errors (in comparison with the $k$-parameter) and highest value of AUC $(0.9911$ for $41 \leq w \leq 46)$ in comparison with 0.982-0.987 for non-normalized diameter. There- fore, the stenosis selection criterion 1 can be formulated as follows:

1) use smoothed values of diameter with the width of smoothing $w=45$ (one of the value with maximum AUC) according to the first formula (3);

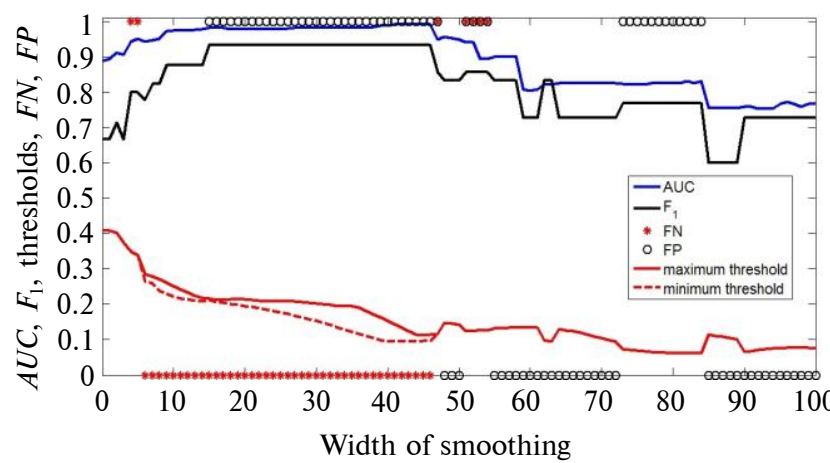

Figure 1: Results of calculations with the use of normalized smoothed VA diameter. ROC characteristics versus the width of smoothing $w$

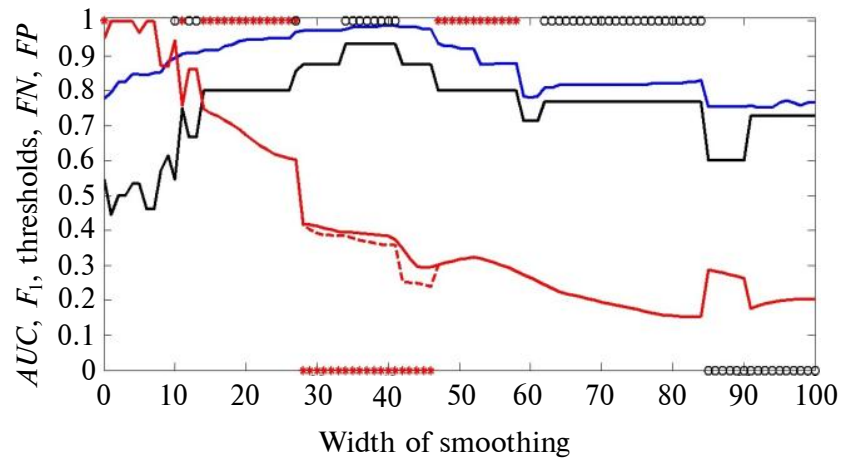

Figure 2: Results of calculations with the use of non-normalized smoothed VA diameter. ROC characteristics versus the width of smoothing $w$. Blue lines represent the $A U C$; black lines $-F_{1}$; red lines - minimum and maximum values of the threshold; red stars - sum of false negative predictions $F N$, black circles - FP

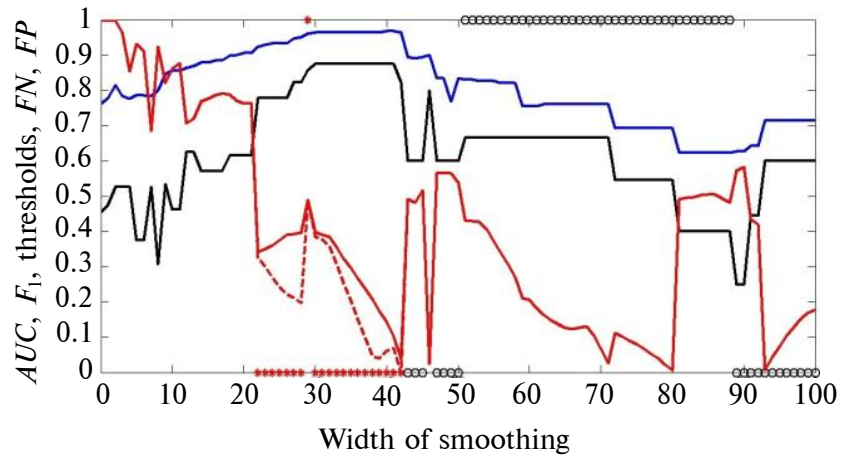

Figure 3: Results of calculations with the use of $k$-parameter and VA diameter data set. ROC characteristics versus the width of smoothing $w$. Blue lines represent the $A U C$; black lines $-F_{1}$; red lines - minimum and maximum values of the threshold; red stars - sum of false negative predictions $F N$, black circles $-F P$ 
2) calculate the average value of the smoothed diameter $\bar{t}$ and the critical value $0.89 \bar{t}$ according to some common value of threshold, shown in Fig. 1 .

3) plot both values on the graph with diameter distributions (blue and red straight lines);

4) the regions of smoothed diameter distributions (black lines) located under two intersections of straight blue lines and under straight red lines can be treated as zones of possible stenosis.

The use of this criterion is illustrated in Figs. 4-6. Blue markers and lines represent the initial diameters, bold black lines show the smoothed diameter distributions.

\section{Using criterion 1 to detect stenosis in internal carotid arteries}

The criterion 1 was developed with the use of VA diameter distributions, which can be treated as learning data sets. To test this criterion, more VA data is necessary. We can try to use this criterion for ICA data, even understanding the difference in shapes and sizes of these two arteries. In particular, the precision of diameter data must be greater for ICA (therefore ICA data needs less smoothing), since the average cross section area of ICA is larger and contains more pixels at the same resolution.

Criterion 1 was applied for 40 ICA diameter data sets. Even after using a more precise value of threshold $-0.8857 \bar{t}-$ and assuming snenosis in case P9-A-left, another false-negative case was found (P2-A-left). Taking into account one falsepositive case (P9-A-right), the calculations with the use of 38 data sets yield: $S E=0.833$, $S P=0.969 ; P P V=0.833 ; F_{1}=0.833$. For two data sets with diagnosis "improved" (P2-B-right and P5-B-left) less artery narrowing was revealed in comparison with cases P2-A-right and P5-A-left. Some results are shown in Fig. 7.

\section{right Patient P1, VA}
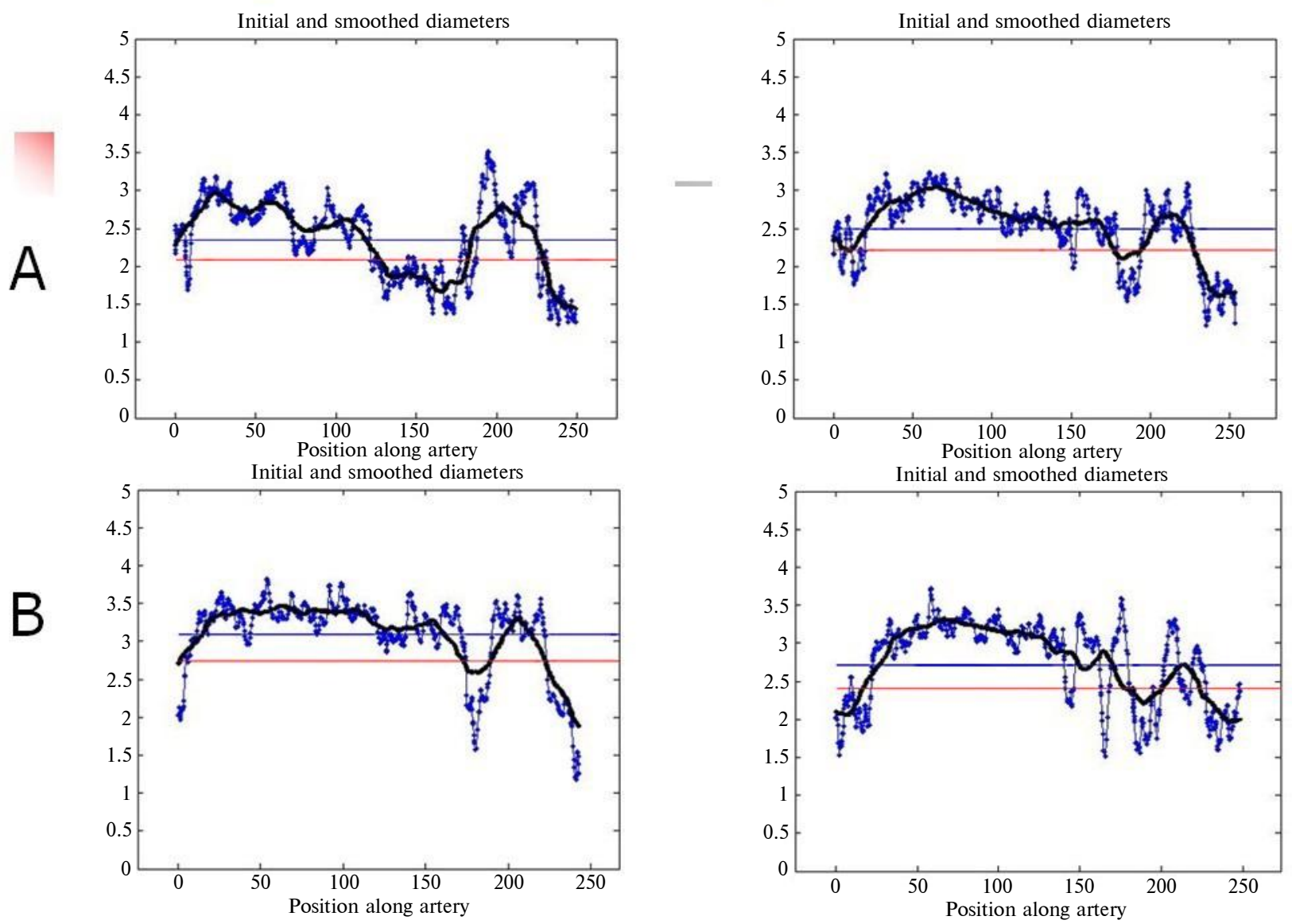

Figure 4: Stenosis is visible in all cases. According to the medical diagnosis there is no stenosis in B-right (a unique $F P$ error) 


\section{right Patient P2, VA left}
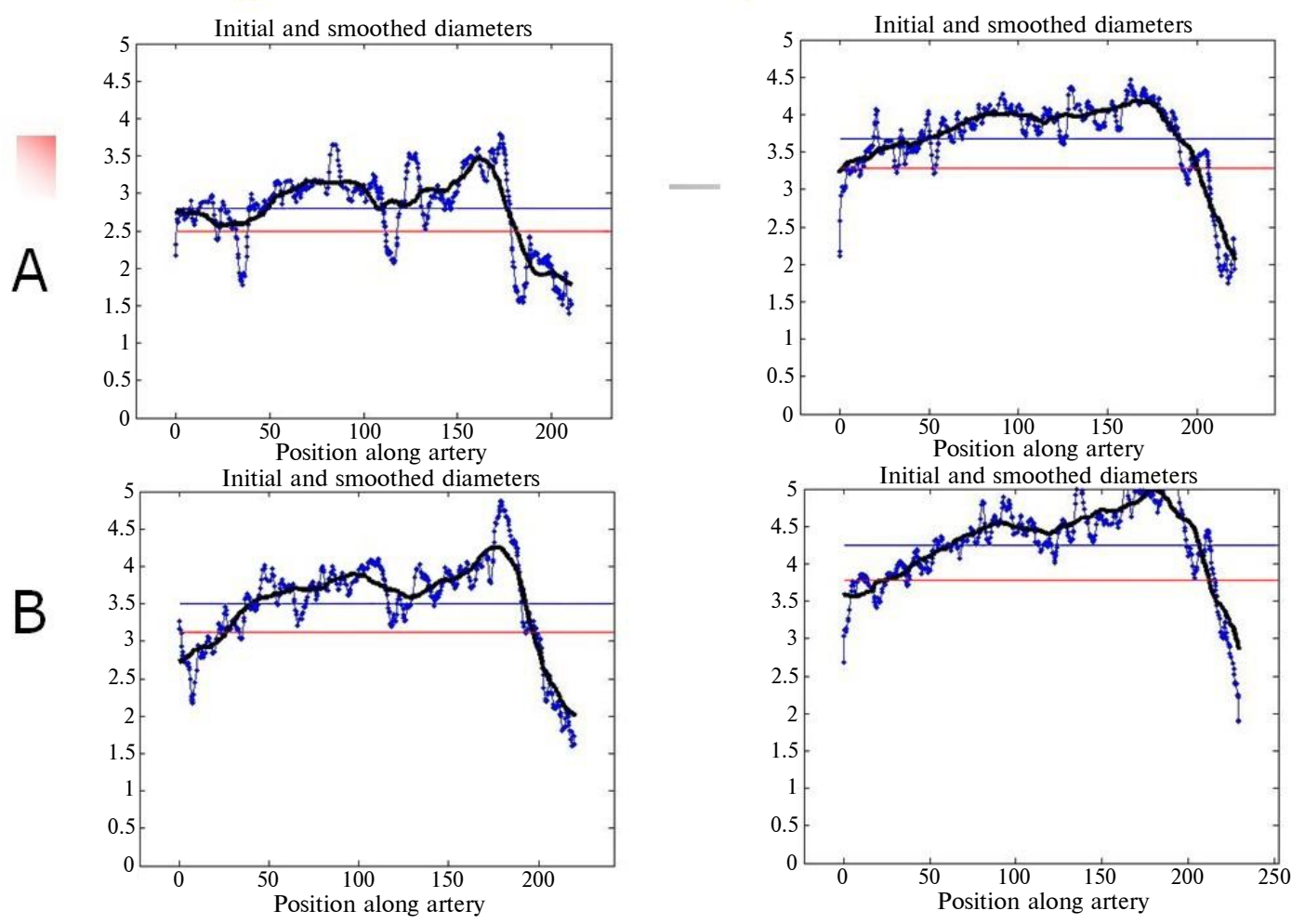

Figure 5: No stenosis in all cases

\section{right Patient P10, VA}
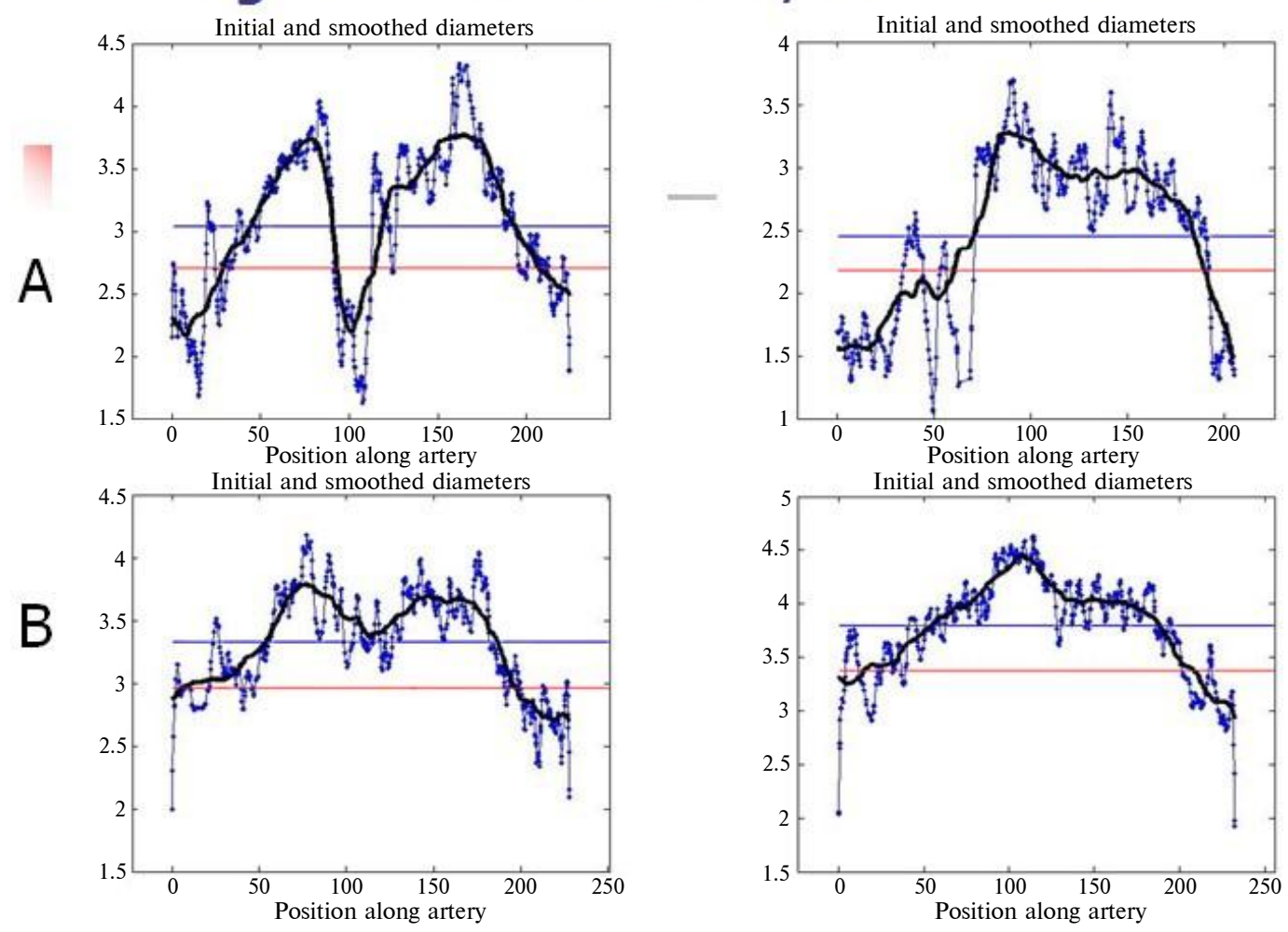

Figure 6: Stenosis in A-right. Closed artery in A-left (unclear diagnosis) show no stenosis after connection the diameter data 


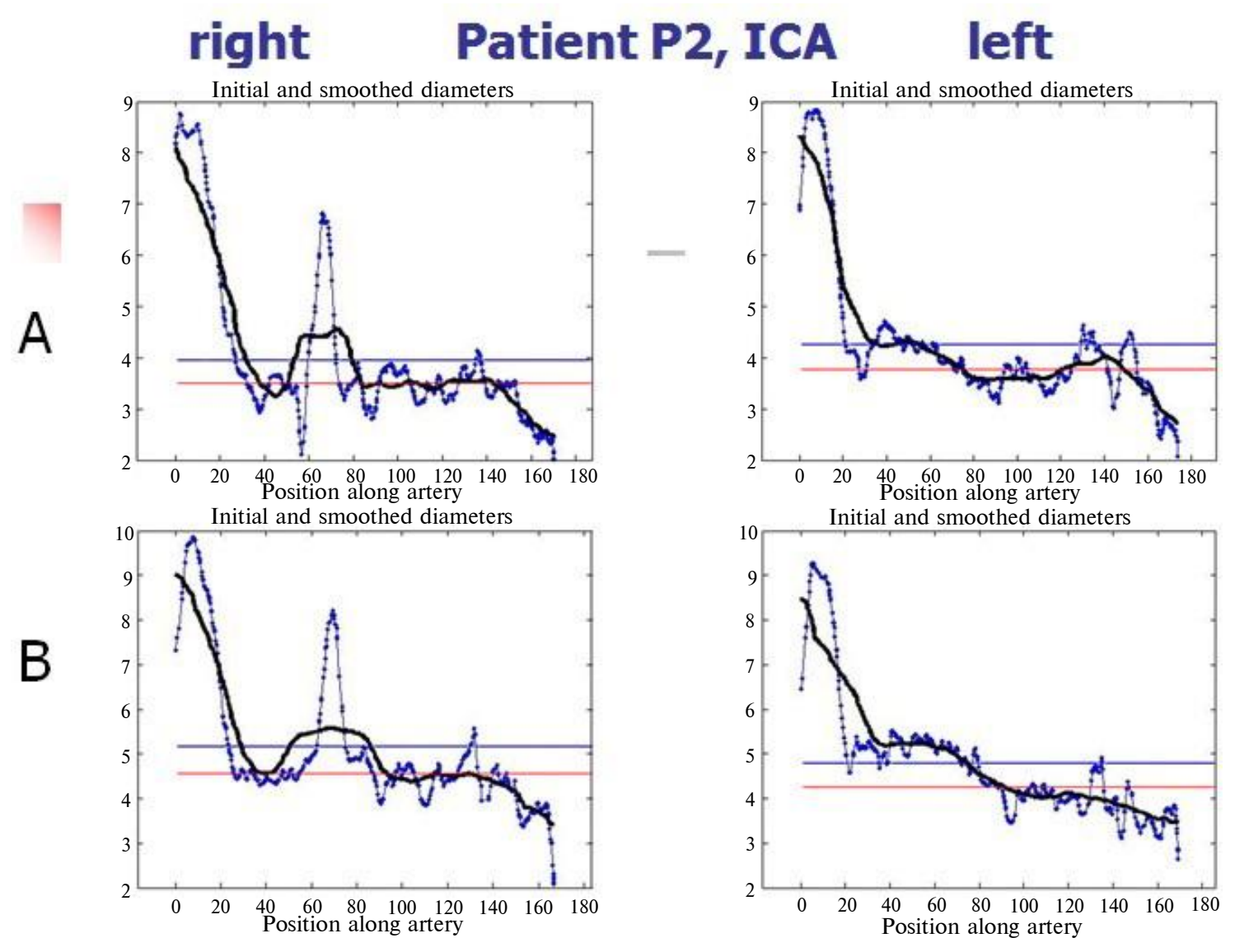

Figure 7: Stenosis in A-r. According to the medical diagnosis there is stenosis in A-1 (a $F N$ error). Unclear diagnosis in B-r ("improved") can be treated as no stenosis

\section{Development and testing of the common crite- rion 2 applicable both for vertebral arteries and internal carotid arteries}

The results of testing the criterion 1 on ICA data sets can be improved with the use of smaller values of the depth of smoothing, since high values of AUC and only one FP error occur in VA at rather large range of $w$ (see Fig. 1). We can try to develop a common criterion 2, which can be applicable for both arteries and yield better testing results. For this purpose we will use the ROC results for ICA data shown in Fig. 8. It can be seen, that there are two ranges of smoothing width $0 \leq w \leq 4$ and $8 \leq w \leq 16$ which ensure only one $F P$ error, no $F N$ results and very high levels AUC. Some intersections of $w$ values can be seen in Table 1 .

Thus, the common criterion 2 applicable both for VA and for ICA can be formulated as follows:

1) use smoothed values of diameter with the width of smoothing $w=16$;
2) calculate the average value of the smoothed diameter $\bar{t}$ and the critical value $0.7925 \bar{t}$;

3) plot both values on the graph with diameter distributions (blue and red straight lines);

4) the regions of smoothed diameter distributions (black lines) located under two intersections of blue lines and under red lines can be treated as zones of possible stenosis.

Application of this criterion for both arteries (77 data sets) yields only two $F P$ cases (one per each artery) and the values $S E=1 ; S P=0.969$; $P P N=0.867 ; F_{1}=0.929$. An example of criterion 2 application for VA data sets is shown in Fig. 9. The application of this criterion to the ICA data is presented in the next Section.

\section{Development and testing of the criterion 3 ap- plicable for non-smoothed internal carotid ar- teries data}

Fig. 8 illustrates that ICA data sets yield very good ROC characteristics for small values of smoothing width $0 \leq w \leq 4$ as well. In particular, 
one $F P$ error, no $F N$ results and very high levels AUC occur with the use of non-smoothed data $(w=0)$. Therefore, the criterion 3, applicable only for ICA can be formulated as follows:

1) use no smoothing

2) calculate the average value of the diameter $\bar{t}$ and the critical value $0.713 \bar{t}$;

3) plot both values on the graph with diameter distributions (blue and red dashed straight lines);

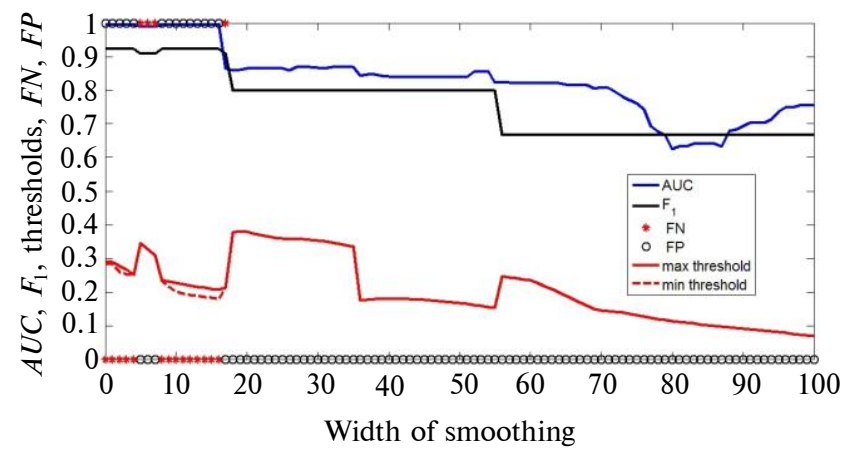

Figure 8: ROC results for ICA data. Normalized diameter. Blue lines represent the AUC; black lines $-F_{1}$; red lines - minimum and maximum values of the threshold; red stars - sum of false negative predictions $F N$, black circles $-F P$
4) the regions of smoothed diameter distributions (black lines) located under two intersections of blue dashed lines and under red dashed lines can be treated as zones of possible stenosis.

Some applications of criteria 2 and 3 to ICA diameter data sets are shown in Figs. 10-12 (blue bold and dashed lines are very close for these cases). It can be seen that application of different criteria can give different results in some cases.

Table 1: Intersection of the smoothing width ranges for vertebral and internal carotid arteries

\begin{tabular}{lcc}
\hline \multicolumn{1}{c}{ Characteristics } & ACI & VA \\
\hline $\begin{array}{l}\text { Range of the smoothing } \\
\text { width } w \text { for cases with }\end{array}$ & $8-16$ & $15-46$ \\
$F N=0 ; F P=1$ & & \\
$A U C$ & 0.9948 & $0.978-0.991$ \\
Sensitivity $S E$ & 1 & 1 \\
Specificity $S P$ & 0.9688 & 0.9688 \\
$P P V$ & 0.857 & 0.875 \\
$F_{1}$ & 0.923 & 0.933 \\
FP Patient & P9-A-right & P1-B-right
\end{tabular}

FP Patient P9-A-right P1-B-right Threshold range for $w=16 \quad 0.179-0.208 \quad 0.206-0.213$ Common threshold

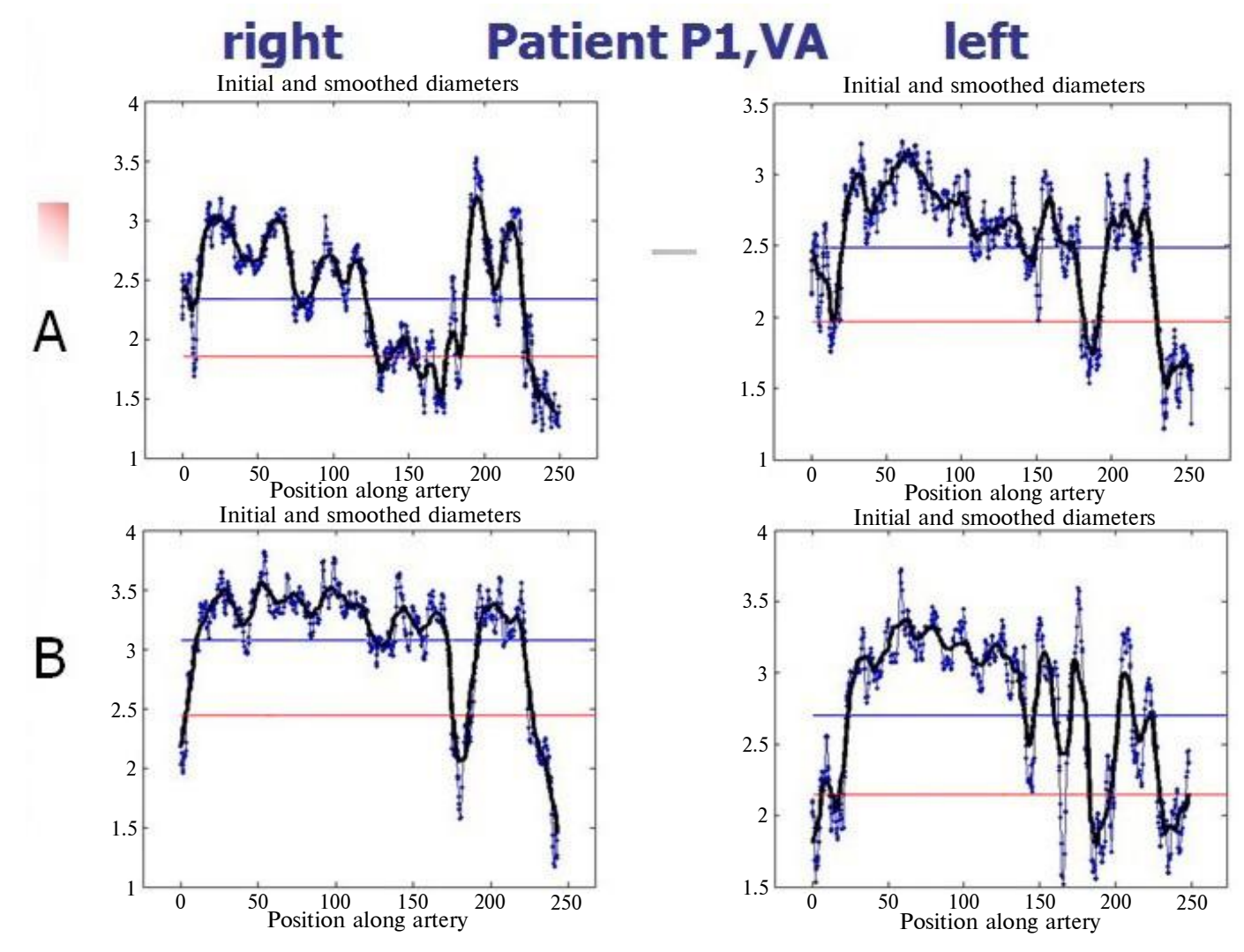

Figure 9: Stenosis in all cases. According to the medical diagnosis, there is no stenosis in in B-r. It is a unique $F P$ error 


\section{right Patient P2, ICA left}
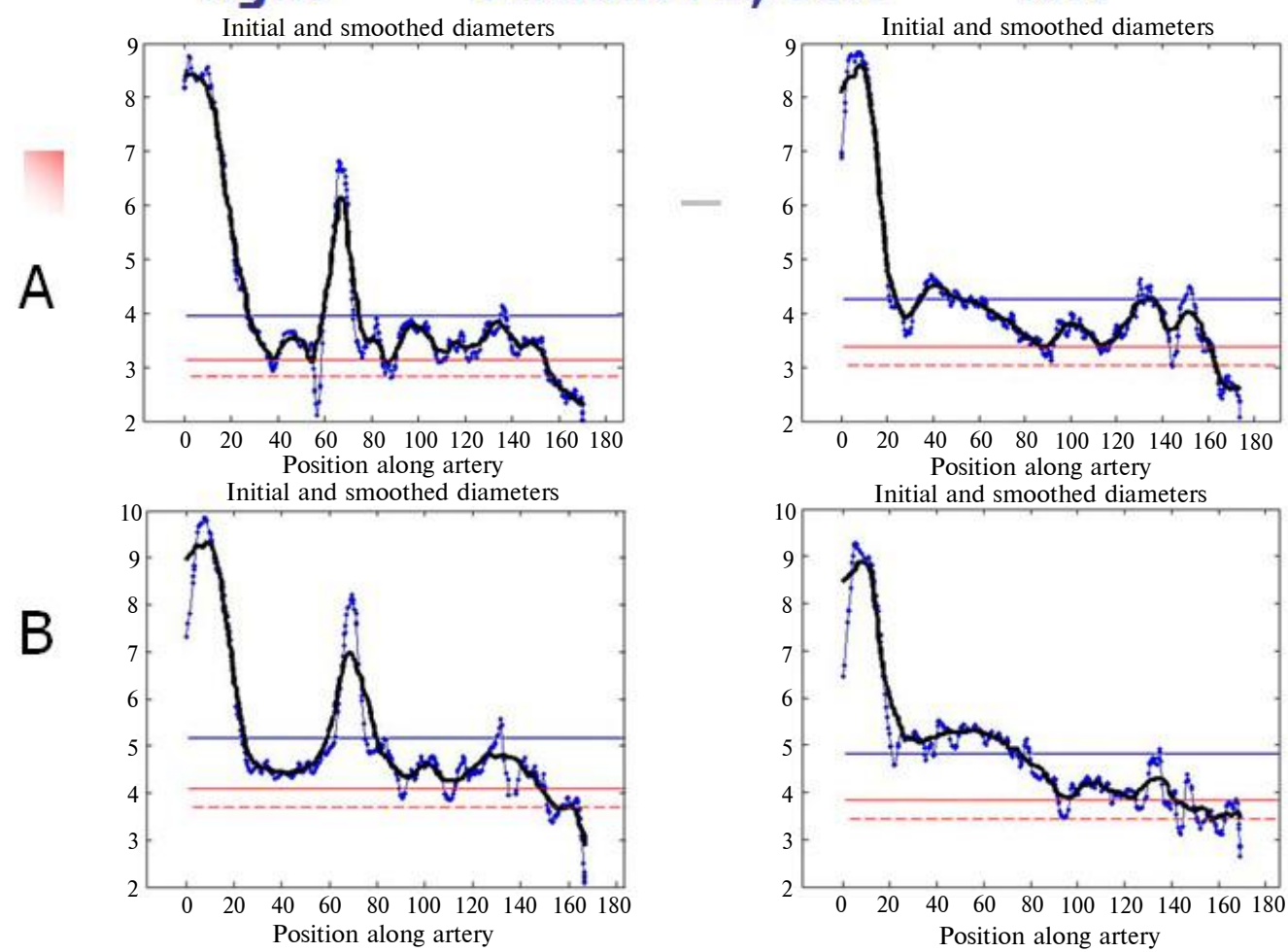

Figure 10: Stenosis in cases A-right and A-left for criteria 2 and 3. Unclear medical diagnosis "improved" in B-right can be treated as no stenosis for the both criteria

\section{right}
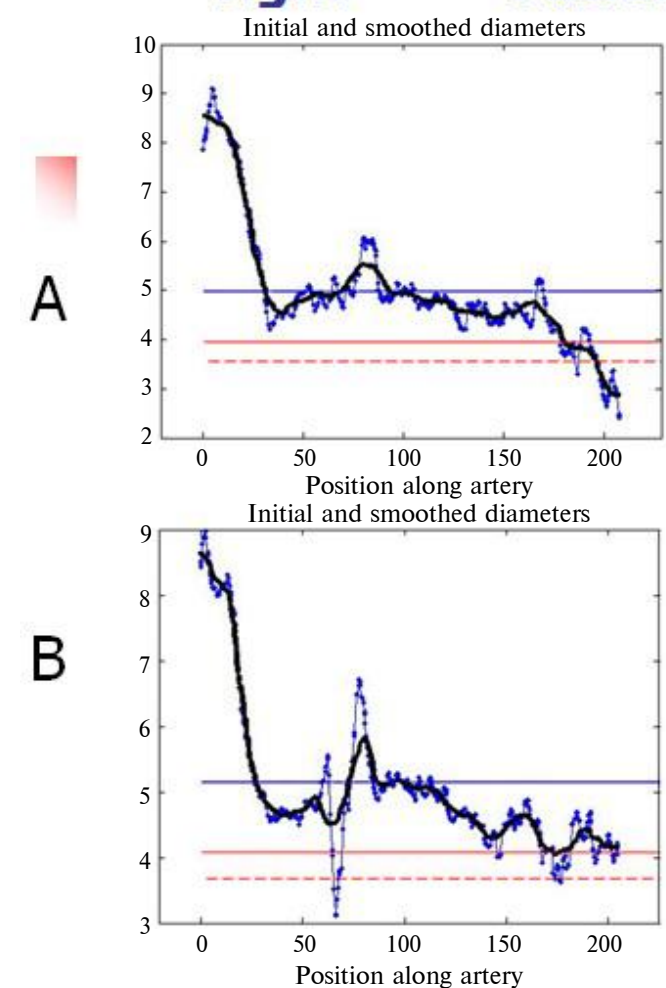

left

Initial and smoothed diameters

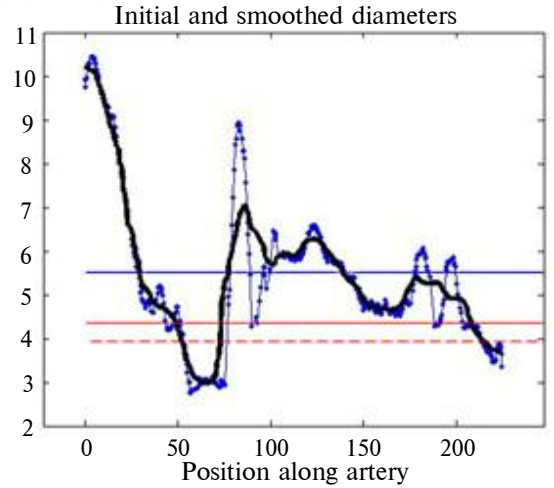

Initial and smoothed diameters

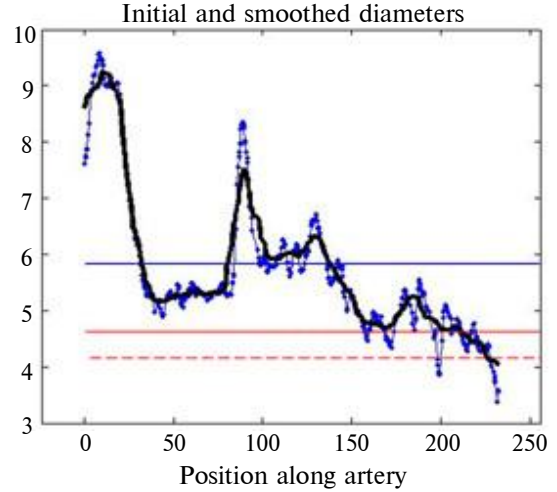

Figure 11: Stenosis in A-left for criteria 2 and 3. Stenosis in B-right for criterion $3(F P)$. Unclear medical diagnosis "improved" in B-left can be treated as no stenosis for the both criteria 


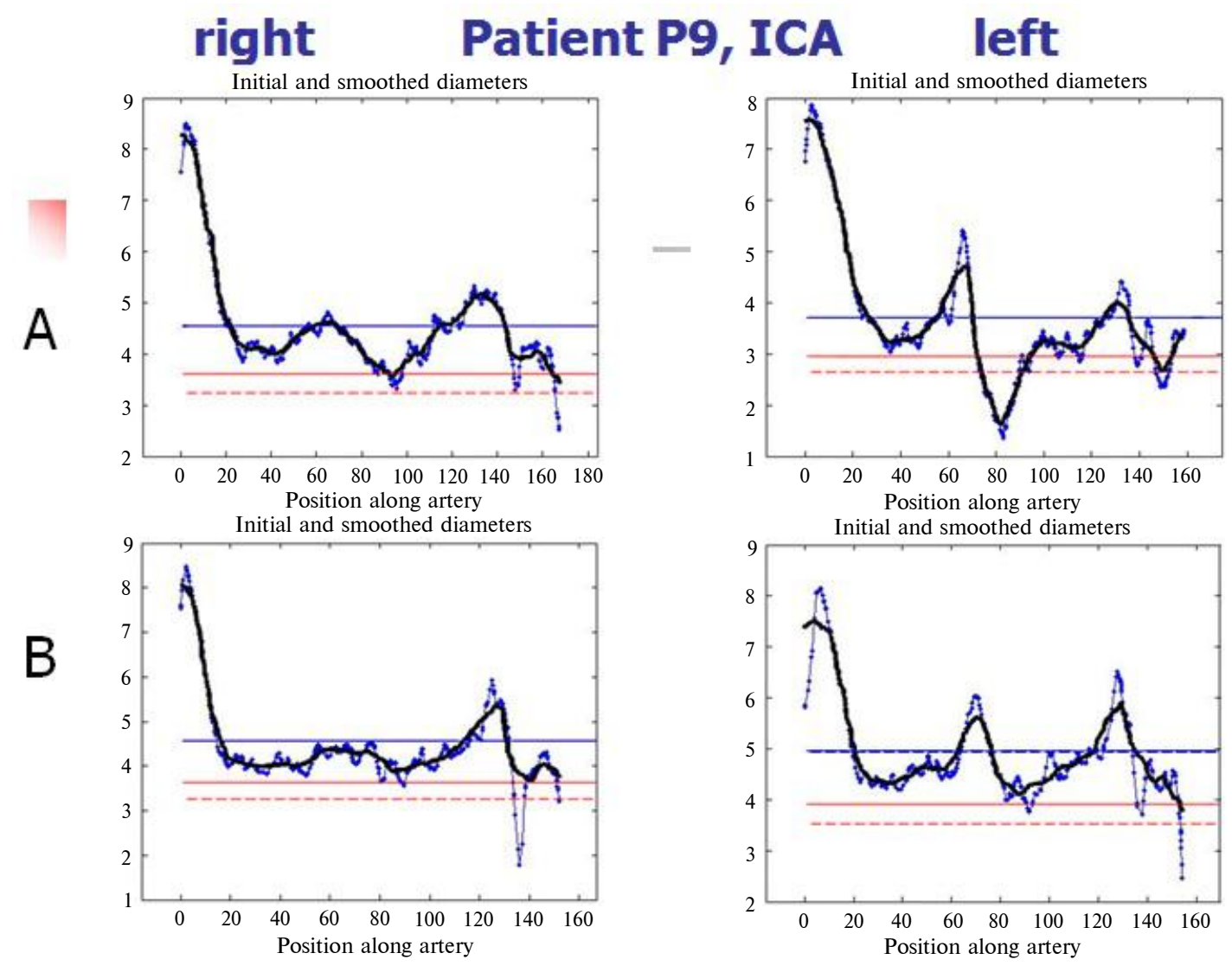

Figure 12: Stenosis in A-1 for criteria 2 and 3. Stenosis in A-r for criterion 2 (FP)

\section{Discussion}

\section{Comparison with the previous results}

The algorithm by Shahzad et al. [2] was applied for the same VA and ICA data sets. The calculated ROC characteristics are presented in Table 2. The optimized values are shown in brackets. Comparison of Tables 1 and 2 demonstrates that criterion 2 ensures higher values of all the characteristics for both arteries.

Table 2: Performance of the algorithm by Shahzad et al. [2] on the considered datasets. Characteristics optimized with the ROC analysis are shown in brackets

\begin{tabular}{ccccc}
\hline Artery & $S E$ & $S P$ & $P P V$ & $F_{1}$ \\
\hline \multirow{2}{*}{ VA } & 1 & 0.636 & 0.368 & 0.539 \\
& $(0.857)$ & $(0.818)$ & $(0.5)$ & $(0.631)$ \\
ICA & 0.625 & 0.875 & 0.556 & 0.558 \\
& $(0.75)$ & $(0.781)$ & $(0.462)$ & $(0.571)$
\end{tabular}

\section{Possible errors in diagnosis}

In order to check the Matlab code and possible errors in medical diagnosis, we have calculated the ROC characteristics assuming the existing stenosis in the case P1-B-right. The results are shown in Fig. 13. It can be seen that for the smoothing range depth $15 \leq w \leq 46$ there are no errors and $\mathrm{AUC}=F_{1}=1$. It is interesting to note that in the case P1-B-right, the stenosis is also flagged with the use of the non-linear characteristics presented below. The results of computations show that there is only this $F P$ error for $6 \leq w \leq 24$.

We have also calculated the ROC characteristics assuming the existing stenosis in ICA for cases P2-B-right and P5-B-left (labeled as "improved"). The results are shown in Fig. 14. It can be seen that the number of errors increases for all values of the smoothing depth. In particular, the minimal number of $F N$ cases is two.

\section{Use of the non-linear characteristics in order to improve the reliability of predictions.}

Criterions 1-3 are based on the normalized diameter data $d_{i}$. In order to check the results and to improve the reliability of predictions, other nonlinear criterions can be used. In particular, the local blood flow velocity in the artery (averaged in time and space for a fixed artery cross-section) is proportional to the cross-section area, i.e., $d_{i}^{2}$ 


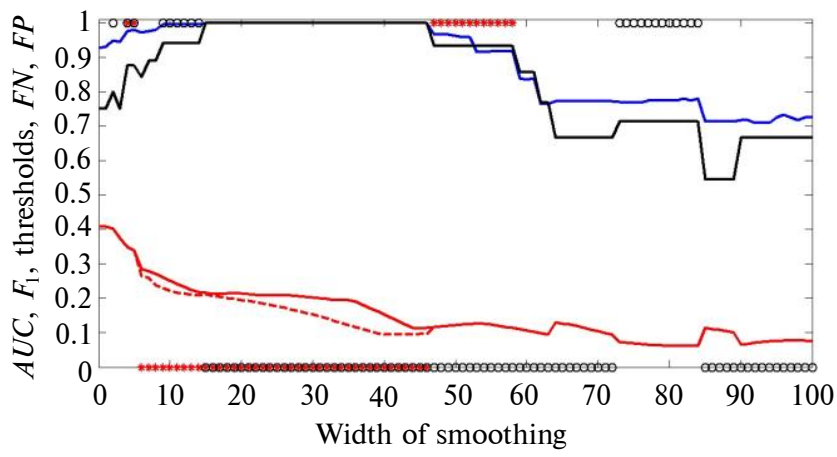

Figure 13: ROC characteristics for VA smoothed normalized diameter sets with the assumption of stenosis in the case P2-Bright. Blue lines represent the $\mathrm{AUC}$; black lines $-F_{1}$; red lines minimum and maximum values of the threshold; red stars sum of false negative predictions $F N$, black circles - FP

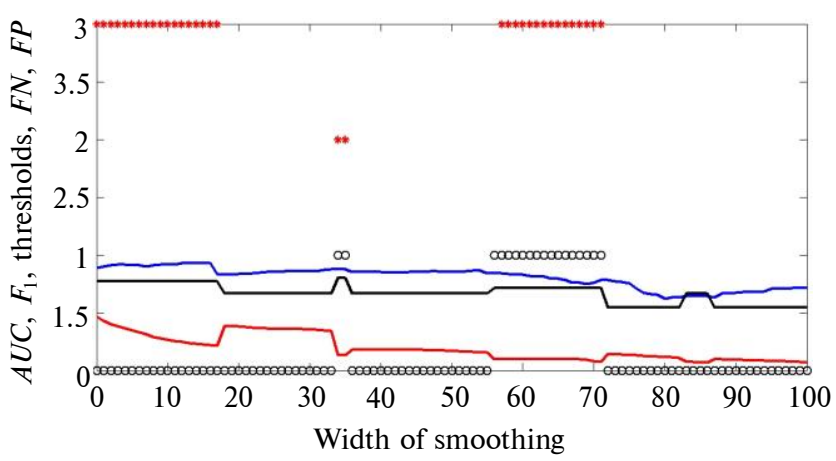

Figure 14: ROC characteristics assuming the existing stenosis in ICA for cases P2-B-right and P5-B-left (labeled as "improved'). Blue lines represent the $\mathrm{AUC}$; black lines $-F_{1}$; red lines - minimum and maximum values of the threshold; red stars - sum of false negative predictions $F N$, black circles $-F P$

Table 3: Optimal solutions with a unique $F N$ or $F P$ error for smoothed normalized linear and non-linear characteristics

\begin{tabular}{|c|c|c|c|c|c|c|}
\hline \multirow[b]{2}{*}{ Characteristic } & \multicolumn{3}{|c|}{ Vertebral arteries } & \multicolumn{3}{|c|}{ Internal carotid arteries } \\
\hline & $d_{i}$ & $d_{i}^{2}$ & $d_{i}^{4}$ & $d_{i}$ & $d_{i}^{2}$ & $d_{i}^{4}$ \\
\hline $\begin{array}{l}\text { Width of } \\
\text { smoothing }\end{array}$ & $15-46$ & $12-42$ & $6-24$ & $\begin{array}{l}\text { a) } 0-4 \\
\text { b) } 8-16\end{array}$ & $0-1$ & $\begin{array}{l}\text { a) } 16-17 \\
\text { b) } 19-25\end{array}$ \\
\hline$A U C$ & $0.978-0.991$ & $0.978-0.991$ & $0.978-0.982$ & a,b) 0.995 & 0.995 & $\begin{array}{l}\text { a) } 0.867 \\
\text { b) } 0.872-0.875\end{array}$ \\
\hline Sensitivity $S E$ & 1 & 1 & 1 & 1 & 1 & 0.833 \\
\hline Specificity $S P$ & 0.969 & 0.969 & 0.969 & 0.969 & 0.969 & 1 \\
\hline$P P N$ & 0.875 & 0.875 & 0.875 & 0.857 & 0.857 & 1 \\
\hline$F_{1}$ & 0.933 & 0.933 & 0.933 & 0.923 & 0.923 & 0.909 \\
\hline Maximal threshold & 0.216 & 0.430 & 0.790 & $\begin{array}{l}\text { a) } 0.290 \\
\text { b) } 0.236\end{array}$ & 0.547 & $\begin{array}{l}\text { a) } 0.735 \\
\text { b) } 0.729\end{array}$ \\
\hline Minimal threshold & 0.095 & 0.187 & 0.580 & $\begin{array}{l}\text { a) } 0.251 \\
\text { b) } 0.179\end{array}$ & 0.492 & $\begin{array}{l}\text { a) } 0.730 \\
\text { b) } 0.726\end{array}$ \\
\hline FP patient & P1-B-right & P1-B-right & P1-B-right & $\begin{array}{l}\text { a) P5-B-right } \\
\text { b) P9-A-right }\end{array}$ & P5-B-right & - \\
\hline FN patient & - & - & - & - & - & a,b) P2-A-left \\
\hline
\end{tabular}

(see, e.g., [11]). Another very important blood flow characteristic - pressure gradient - is connected with the squared cross-section area, i.e., $d_{i}^{4}$ (see, e.g., [12]).

Two series of computations were performed with the use of smoothed normalized cross-section area $\left(d_{i}^{2}\right)$ and smoothed normalized squared crosssection area $\left(d_{i}^{4}\right)$. The results showed that a unique $F N$ or FP error exists both for VA and ICA for some ranges of the smoothing width shown in Table 3. No cases without any errors were revealed. For normalized diameter of ICA there are two ranges of the smoothing width, corresponding to a unique $F P$ error, which occurs in different patients (see Table 3 ). For smoothed normalized squared cross-section area $\left(d_{i}^{4}\right)$ of ICA, there are two ranges of the smoothing width, corresponding to a unique $F N$ error, which occurs in the same patient (see Table 3 ).

\section{Conclusions}

Different linear, non-linear, smoothed, and non-smoothed parameters and receiver operating characteristic (ROC) were applied to detect stenosis in vertebral and internal carotid arteries. Real diameter data of 10 patients (80 data sets were used).

Three different criteria were proposed for stenosis detection. It was shown that smoothed data are necessary for VA and the criterion applicable both for VA and ICA. For ICA it is possible to use initial (unsmoothed) data. Only one False Positive case was detected for every artery. 
Results of application of proposed criteria are presented, tested and discussed. For VA it is possible to use criteria 1 and 2 and smoothed normalized diameter data. For ICA criterion 2 can be recommended to detect long enough narrowing areas. To detect short zones of stenosis in ICA, the criterion 3 is useful, since it uses the non-smoothed diameter data.

To minimize the number of FN cases we recommend to use both the criteria 1 and 2 for VA and both the criteria 2 and 3 for ICA. It would be useful to develop corresponding user-friendly interface.

\section{Acknowledgements}

The authors thank Professor S. Pereverzyev (RICAM, Linz, Ausria) for his assistance and very useful discussions. The study was supported by EU-financed Horizon-2020 project AMMODIT (Grant Number MSCA-RISE 645672).

Sergiy Pereverzyev Jr. gratefully acknowledges the support of the Austrian Science Fund (FWF): project P 29514-N32. The data was acquired through a study performed at the Medical University of Innsbruck called "ReSect-Study". The ReSect-study is funded by the OeNB Anniversary Fund (\#15644).

\section{References}

[1] Kirişli H, Schaap M, Metz CT, Dharampal AS, Meijboom WB, Papadopoulou SL, et al. Standardized evaluation framework for evaluating coronary artery stenosis detection, stenosis quantification and lumen segmentation algorithms in computed tomography angiography. Medical Image Analysis. 2020;17(8):859-76. DOI: 10.1016/j.media.2013.05.007

[2] Shahzad R, van Walsum T, Kirisli H, Tang, H. Automatic stenoses detection, quantification and lumen segmentation of the coronary arteries using a two point centerline extraction scheme. In: Proceedings of MICCAI Workshop 3D Cardiovascular Imaging: A MICCAI Segmentation Challenge; 2012.

[3] Mayer L, Boehme C, Toell T, Dejakum B, Willeit J, Schmidauer C, et al. Local signs and symptoms in spontaneous cervical artery dissection: a single centre cohort study. J Stroke. 2019;21(1):112. DOI: 10.5853/jos.2018.03055

[4] Yushkevich PA, Piven J, Hazlett HC, Smith RG, Ho S, Gee JC, et al. User-guided 3D active contour segmentation of anatomical structures: significantly improved efficiency and reliability. Neuroimage. 2006;31(3):1116-28. DOI: 10.1016/j.neuroimage.2006.01.015

[5] Quek F, Kirbas C. Vessel extraction in medical images by wVAe propagation and trace-back. IEEE Trans Med Imaging. 2001;20(2):117-31. DOI: 10.1109/42.913178

[6] Raman V, Then P. Novelty towards hybrid segmentation of coronary artery in CT cardiac images. In: Ninth ACIS International Conference on Software Engineering, Artificial Intel-ligence, Networking, and Parallel/Distributed Computing; 2008. p. 513-16. DOI: 10.1109 /snpd.2008.53

[7] Benmansour F, Cohen LD. A new interactive method for coronary arteries segmentation based on tubular anisotropy. In: IEEE International Symposium on Biomedical Imaging: From Nano to Macro; 2009. p. 41-4. DOI: 10.1109/isbi.2009.5192978

[8] Chen K, Zhang Y, Pohl K, Syeda-Mahmood T, Song Z, Wong STC. Coronary artery segmentation using geometric moments-based tracking and snake-driven refinement. In: Annual International Conference of the IEEE Engineering in Medicine and Biology Society (EMBS); 2010. p. 3133-7. DOI: 10.1109/iembs.2010.5627192

[9] Xu Y, Liang G, Hu G, Yang Y, Geng J, Saha PK. Quantification of coronary arterial stenoses in CTA using fuzzy distance transform. Comput Med Imaging Graph. 2012;36(1):11-24. DOI: 10.1016/j.compmedimag.2011.03.004

[10] Yang G, Broersen A, Petr R, Kitslaar P, de Graaf MA, Bax JJ, et al. Automatic coronary artery tree labeling in coronary computed tomographic angiography datasets. In: 2011 Computing in Cardiology; Hangzhou; 2011. p. 109-12.

[11] Nesteruk I, Redaelli A, Kudybyn I, Piatti F, Sturla F. Global and local characteristics of the blood flow in large vessels based on 4D MRI data. Naukovi Visti NTUU KPI. 2017;2:37-44. DOI: 10.20535/1810-0546.2017.2.99724

[12] Nesteruk I, Piatti F, Sytnyk D, Redaelli A. Differentiation of the 4D MRI blood flow data to estimate the vorticity and shear stress in aorta, pulmonary artery and the heart. In: Proceedings of 2019 IEEE 39th Internatiomal Conference on Electronics and Nanotechnology; Kyiv; 2019, Apr 16-18. p. 415-20. DOI: 10.1109/elnano.2019.8783689

[13] Öksüz İ, Ünay D, Kadıpaşaoğlu K. A hybrid method for coronary artery stenoses detection and quantificationin CTA images [Internet]. Pdfs.semanticscholar.org. 2020 [cited 2020 May 25]. Available from: https://pdfs.semanticscholar.org/430e/140319a63da9c9b0c52559a5d7ff185bf23e.pdf

[14] Hajian-Tilaki K. Receiver operating characteristic (ROC) curve analysis for medical diagnostic test evaluation. Caspian J Intern Med. 2013;4(2):627-35. 
І.Г. Нестерук, С. Переверзєв Мол., Л. Майер, Р. Штайгер, Л. Кустачер, К. Фрічер, М. Кнофлах, Е.Р. Гізевські

\section{ВИЯВЛЕННЯ СТЕНОЗУ У ВНУТРІШНІХ СОННИХ І ХРЕБЕТНИХ АРТЕРІЯХ ІЗ ЗАСТОСУВАННЯМ ДІАМЕТРІВ, ОЦІНЕНИХ ЗА ДАНИМИ МАГНІТНО-РЕЗОНАНСНОÏ ТОМОГРАФIÏ}

Проблематика. Магнітно-резонансна томографія (MPT) дає можливість визначити діаметр судин in vivo. Ця методика може мати проривний вплив на оцінку, стратифікацію ризику і терапевтичне планування при гемодинамічних патологіях, наприклад при артеріальному стенозі. Однак його клінічне застосування обмежене через складну постобробку, необхідну для витягу інформації, та труднощі синтезу отриманих даних у клінічно корисні параметри.

Мета. Ми використовуємо розподіл діаметра судини вздовж ії центральної лінії, отриманий із застосуванням технології МРТ, щоб виявити наявність стенозу у внутрішніх сонних (ICA) і хребетних (VA) артеріях з мінімальною кількістю помилкових негативних прогнозів та оцінити ефективність терапії.

Методика реалізації. Спеціальні нормовані та згладжені характеристики застосовано для розробки критеріїв виявлення стенозу, які можна використовувати для кожної артерії окремо і для обох судин одночасно. Для підвищення достовірності діагностики використовували лінійні та нелінійні характеристики. Дослідження базується на робочих характеристиках приймача (ROC) i методах оптимізації. Було використано дані про фактичний діаметр судин 10 пацієнтів (80 наборів даних).

Результати. Для виявлення стенозу запропоновано три різних критерії, що базуються на оптимальних параметрах згладжування розподілів діаметра судин і відповідних порогових значеннях для лінійних та нелінійних характеристик. Використання розроблених критеріїв дає змогу підвищити надійність виявлення стенозу.

Висновки. Для виявлення стенозу у внутрішніх сонних і хребетних артеріях застосовувались різні лінійні, нелінійні, згладжені й незгладжені параметри та ROC. Було показано, що згладжені дані необхідні для VA і критерію, застосовного як для VA, так і для ICA. Для ICA можна використовувати початкові (незгладжені) дані. Виявлено лише один хибний позитивний випадок для кожної артерії. Представлено, перевірено та обговорено результати застосування запропонованих критеріїв. Для VA можна використовувати критерії 1 і 2 і згладжувати дані нормалізованого діаметра. Для ICA критерій 2 можна рекомендувати для виявлення досить довгих зон звуження. Для виявлення коротких зон стенозу в ICA корисний критерій 3, оскільки він використовує дані незгладженого діаметра.

Ключові слова: стеноз; внутрішні сонні артерії; хребетні артерії; магнітно-резонансна томографія; комп'ютеризована ангіографія; робоча характеристика приймача; оптимізація.

\section{И.Г. Нестерук, С. Переверзев Мл., Л. Майер, Р. Штайгер, Л. Кусстачер, К. Фричер, М. Кнофлах, Э.Р. Гизевски}

\section{ОБНАРУЖЕНИЕ СТЕНОЗА ВНУТРЕННИХ СОННЫХ И ПОЗВОНОЧНЫХ АРТЕРИЙ С ИСПОЛЬЗОВАНИЕМ ДИАМЕТРОВ, ОЦЕНЕННЫХ ПО ДАННЫМ МАГНИТНО-РЕЗОНАНСНОЙ ТОМОГРАФИИ}

Проблематика. Магнитно-резонансная томография (МРТ) дает возможность количественно определить диаметры сосудов in vivo. Этот метод может оказать прорывное влияние на оценку, стратификацию риска и терапевтическое планирование при гемодинамических патологиях, например при артериальном стенозе. Однако его применимость в клиниках ограничена из-за сложной постобработки, необходимой для извлечения информации, и сложности с синтезом полученных данных в клинически полезные параметры.

Цель. Мы используем распределение диаметра сосуда вдоль ее центральной линии, полученное с использованием технологии MPT, чтобы обнаружить наличие стеноза во внутренних сонных артериях (ICA) и позвоночных артериях (VA) c минимальным количеством ложных отрицательных прогнозов и оценить эффективность терапии.

Методика реализации. Специальные нормализованные и сглаженные характеристики будут использоваться для разработки критериев обнаружения стеноза, которые можно использовать для каждой артерии отдельно и для обоих сосудов одновременно. Линейные и нелинейные характеристики были использованы для повышения достоверности прогнозов. Исследование основано на эксплуатационных характеристиках приемника (ROC) и методах оптимизации. Использовались данные реального диаметра артерий для 10 пациентов (80 наборов данных).

Результаты. Для выявления стеноза были предложены три различных критерия, основанные на оптимальных параметрах сглаживания распределений диаметра сосудов и соответствующих пороговых значениях для линейных и нелинейных характеристик. Использование разработанных критериев позволяет повысить надежность выявления стеноза.

Выводы. Различные линейные, нелинейные, сглаженные и несглаженные параметры и ROC были использованы для обнаружения стеноза во внутренних сонных и позвоночных артериях. Было показано, что сглаженные данные необходимы для VA и критерия, применимого как для VA, так и для ICA. Для ICA можно использовать исходные (несглаженные) данные. Только один ложноположительный случай был обнаружен для каждой артерии. Представлены, апробированы и обсуждены результаты применения предложенных критериев. Для VA можно использовать критерии 1 и 2 и сглаженные данные нормализованного диаметра. Для ICA критерий 2 можно рекомендовать для обнаружения достаточно длинных сужающихся участков. Для выявления коротких зон стеноза в ICA полезен критерий 3, поскольку в нем используются несглаженные данные диаметра.

Ключевые слова: стеноз; внутренние сонные артерии; позвоночные артерии; магнитно-резонансная томографрия; компьютеризованная ангиография; рабочие характеристики приемника; оптимизация 